\title{
LOCAL CONDUCT AND THE SHERMAN ACT ${ }^{*}$
}

\author{
Milton A. Kalim $\dagger$
}

VER SINCE the passage of the Sherman Act, the problem of its
applicability to local conduct has been a recurring one which has

* The views expressed in this article are those of the author and are not necessarily those of any government agency.

$\dagger$ Ph.B. 1930, University of Chicago; A.M. 1932, George Washington University; LL.B. 1921, Northwestern University; S.J.D. 1933, Harvard University. Menber of the Illinois and District of Columbia bars; Trial Attorney, Antitrust Division, Department of Justice. Former member of law faculties of Northwestern University, Howard University, University of Kansas, Chicago-Kent College of Law, and National University.

126 Stat. 209 (1890), 15 U.S.C. \$§ 1-7 (1952):

« 1 . Trusts, etc., in restraint of trade illegal; exception of resale price agreements; penalty

"Every contract, combination in the form of trust or otherwise, or conspiracy, in restraint of trade or commerce among the several States, or with foreign nations, is declared to be illegal: Provided, That nothing contained in sections $1-7$ of this title shall render illegal, contracts or agreements prescribing minimum prices for the resale of a commodity which bears, or the label or container of which bears, the trade inark, brand, or name of the producer or distributor of such commodity and which is in free and open competition with commodities of the same general class produced or distributed by others, when contracts or agreements of that description are lawful as applied to intrastate transactions, under any statute, law, or public policy now or hereafter in effect in any State, Territory, or the District of Columbia in which such resale is to be made, or to which the commodity is to be transported for such resale, and the making of such contracts or agreements shall not be an unfair method of competition under section 45 of this title: Provided further, That the preceding proviso shall not make lawful any contract or agreement, providing for the establishment or maintenance of minimum resale prices on any commodity herein involved, between manufacturers, or between producers, or between wholesalers, or between brokers, or between factors, or between retailers, or between persons, firms, or corporations in competition with each other. Every person who shall make any contract or engage in any combination or conspiracy declared by sections 1-7 of this title to be illegal shall be deened guilty of a misdemeanor, and, on conviction thereof, shall be punished by fine not exceeding $\$ 5,000$, or by imprisonment not exceeding one year, or by both said punishments, in the discretion of the court.

"§ 2. Monopolizing trade a misdemeanor; penalty

"Every person who shall monopolize, or attempt to monopolize, or combine or conspire with any other person or persons, to monopolize any part of the trade or 
occasioned extensive debate and litigation. The Act purports only to regulate interstate commerce, ${ }^{2}$ but this merely poses the vital question

commerce among the several States, or with foreign nations, shall be deemed guilty of a misdemeanor, and, on conviction thereof, shall be punished by fine not exceeding fifty thousand dollars, or by imprisonment not exceeding one year, or by both said punishments, in the discretion of the court.

"§ 3. Trusts in Territories or District of Columbia illegal; combination a misdemeanor "Every contract, combination in form of trust or otherwise, or conspiracy, in restraint of trade or commerce in any Territory of the United States or of the District of Columbia, or in restraint of trade or commerce between any such Territory and another, or between any such Territory or Territories and any State or States or the District of Columbia, or with foreign nations, or between the District of Columbia and any State or States or foreign nations, is declared illegal. Every person who shall inake any such contract or engage in any such combination or conspiracy, shall be deemed guilty of a misdemeanor, and, on conviction thereof, shall be punished by fine not exceeding fifty thousand dollars, or by imprisonment not exceeding one year, or by both said punishments, in the dicretion of the court.

"\$ 4. Jurisdiction of courts; duty of district attorneys; procedure

"The several district courts of the United States are invested with jurisdiction to prevent and restrain violations of sections $1-7$ of this title; and it shall be the duty of the several district attorneys of the United States, in their respective districts, under the direction of the Attorney General, to institute proceedings in equity to prevent and restrain such violations. Such proceedings may be by way of petition setting forth the case and praying that such violation shall be enjoined or otherwise prohibited. When the parties complained of shall have been duly notified of such petition the court shall proceed, as soon as may be, to the hearing and determination of the case; and pending such petition and before final decree, the court may at any time make such temporary restraining order or prohibition as shall be deemed just in the premises.

" $\$$ 5. Bringing in additional parties

"Whenever it shall appear to the court before which any proceeding under section 4 of this title may be pending, that the ends of justice require that other parties should be brought before the court, the court may cause them to be summoned, whether they reside in the district in which the court is held or not; and subpoenas to that end may be served in any district by the marshal thereof.

" $\$ 6$. Forfeiture of property in transit

"Any property owned under any contract or by any combination, or pursuant to any conspiracy (and being the subject thereof) mentioned in section 1 of this title, and being in the course of transportation from one State to another, or to a foreign country, shall be forfeited to the United States, and may be seized and condemned by like proceedings as those provided by law for the forfeiture, seizure, and condemnation of property imported into the United States contrary to law.

"§ 7. 'Person' defined

'The word 'person,' or 'persons,' wherever used in sections $1-7$ of this title shall be deemed to include corporations and associations existing under or authorized by the laws of either the United States, the laws of any of the Territories, the laws of any State, or the laws of any foreign country."

${ }^{2}$ United, States v. Shubert, 348 U.S. 222, 226 (1955); United States v. SouthEastern Underwriters Association, 322 U.S. 533, 549-550 (1944), and cases cited therein. For an excellent analysis of the meaning of interstate commerce and the 
of whether there is, in fact, any legal distinction between "interstate commerce" and "intrastate commerce affecting interstate commerce," and if so, what kind of purely local conduct may be within the reach of the Act. Although the subleties which are involved here are significant, they have received but scant attention from the courts.

For example, a combination to fix the price of a commodity in interstate commerce is a per se violation of the Sherman Act. ${ }^{3}$ On the other hand, a price-fixing agreement which is made either before the flow of interstate commerce has begun or after it has ended is an offense only if it has some effect on interstate commerce. This latter principle, now known as the "affectation doctrine"-a phrase first used by Mr. Justice Rutledge in Mandeville Farms v. Sugar Co. ${ }^{5}$-has had a most curious and erratic history, but at long last, it seems to have achieved some degree of stability. This paper will trace its evolution and examine some of its substantive contents and procedural effects.

In the first Sherman Act lawsuit to confront the Supreme Court, United States v. E. C. Knight, ${ }^{6}$ the validity of a series of mergers in the sugar-refining industry was questioned. The Court, in resolving the issue, expressly distinguished between production and interstate commerce, and concluded that the antitrust laws applied only to the latter.

scope of the commerce power, see Stern, The Scope of the Phrase "Interstate Commerce," 4I A.B.A.J. 823 (1955).

${ }^{3}$ United States v. Socony-Vacuum Oil Co., 3 10 U.S. I50 (1940); United States v. Detroit Sheet Metal and Roofing Ass'n, I 16 F. Supp. 8I (E.D. Mich. 1953). See Northern Pacific Railway Co. v. United States, 356 U.S. I, 5, 6 (1958), where the Court explained its rationale for adjudicating certain acts to be per se violations of the Sherman Act and specified certain practices which the courts have deemed illegal in and of themselves. These are (a) price fixing, (b) division of markets, (c) group boycotts, and (d) tying arrangements. The Court considered that these transactions not only have a pernicious effect on competition, but also lacked any redeeming virtue. The Court, therefore, conclusively presumed such conduct to be unreasonable in fact, and, accordingly, held it to be contrary to law. By this judicial process the Court avoided an elaborate inquiry as to the precise harm which results from any of these four kinds of conduct or the economic justification for its use.

"United States v. Starlite Drive-In, Inc., 204 F.2d 4 99 (7th Cir. 1953); United States v. Greater Kansas City Chapter Nat'I Electrical Contractors Ass'n, 82 F. Supp. r47 (W.D. Mo. 1949). See also United States v. Yellow Cab Co., 332 U.S. 218 (1947), and United States v. Oregon State Med. Soc'y, 343 U.S. 326 (1952), for the necessity of some adverse effect on interstate commerce by local conduct. See also Mande. ville Farms v. Sugar Co., 334 U.S. 219 (1948); Las Vegas Merchant Plumbers Ass'n v. United States, 210 F.2d 732 (gth Cir.), cert. denied, 348 U.S. 817 (1954).

334 U.S. 219,232 (1948).

156.U.S. I (1895). 
Thus, it held that a monopoly in the manufacture of sugar was beyond the reach of the Sherman Act. ${ }^{7}$

Almost at once, however, this "local conduct" doctrine began to undergo a process of erosion, in the course of which the Supreme Court freely applied the antitrust laws to acts occurring before there had been any movement across state lines. First, in Addyston Pipe E Steel Co. v. United States, ${ }^{8}$ the Court, abandoning a narrow, atomistic approach and looking rather to the future of the goods in question, saw a direct and immediate, and not an indirect and incidental, adverse effect on the goods' interstate movement and found a Sherman Act violation. ${ }^{\text {' }}$ Shortly thereafter, the Court, in Bement v. National Harrow Co., ${ }^{10}$ although still citing the Knight case as governing law, held it inapplicable in a situation where not only the production of goods, but also their sale throughout the country at noncompetitive prices was involved. In Swift v. United States, ${ }^{11}$ too, the Court, finding a Sherman Act violation in terms of both a purpose to restrain and to monopolize and an effect upon interstate commerce that was not "accidental, secondary, remote or merely probable,"12 dismissed the Knight case with the observation that the conduct of the defendants there did not have interstate monopoly as a "primary end" or "necessary consequence."13 The Court acknowledged, however, that at times, the line which separates intrastate from interstate commerce is a rather fine one..$^{14}$

The next in this series of cases, Loevee v. Lawlor, ${ }^{15}$ was a leading

TThe Court rejected the argument of the Government that the power to control the manufacture of refined sugar was a monopoly over a necessary of life and that interstate commerce was thus indispensable for the consumption of sugar by much of the country's population, noting that "the fact that an article is manufactured for export to another State does not of itself make it an article of interstate commerce. ..." Id. at 13 .

I75 U.S. 211 ( 1899 ).

The Court said: "The direct purpose of the combination in the $K$ night case was the control of the manufacture of sugar. There was no combination or agreement, in terms, regarding the future disposition of the manufactured article; nothing looking to a transaction in the nature of interstate commerce." Id. at 240.

${ }^{10} 186$ U.S. 70 (1902).

12 Id. at 397 .

22196 U.S. 375 (1905).

16 "[The Knight and the Swift] cases are near to each other, as sooner or later always must happen wherc lines are to be drawn, but the line between them is distinct." Ibid.

${ }^{25} 208$ U.S. 274 (1908) (commonly known as the Danbury Hatters case). The application of the Sherman Act to labor union activities has since suffered some basic restrictions as a result of Apex Hosiery Co. v. Leader, 310 U.S. 469 (1940), and United States v. Hutcheson, 312 U.S. 219 (194r), which held (a) that commercial competition must be adversely affected by union activities, and (b) that an interlacing of 
antitrust case before the passage of the Clayton and Norris-LaGuardia Acts ${ }^{16}$ and was largely responsible for this subsequent legislation which partially exempted organized labor from the federal antitrust laws. Here, the Supreme Court held that the Sherman Act prohibitions applied to the boycott activities of a union and its member-employees of a hat manufacturer in one state and his customers in other states. In so reasoning, the Court made short shrift of the Knight case. ${ }^{17}$ It remained only for the landmark Standard Oil Co. v. United States, ${ }^{18}$ to deal the Knight doctrine its unequivocally disabling blow. Later cases which referred to the Knight case served only further to sap its waning vitality. ${ }^{19}$

the Sherman, Clayton, and Norris-LaGuardia Acts created a statutory exemption from the antitrust laws for the conduct involved. Since intrastate commerce was not the focal point of reference or of issue in these cases, this paper will not dwell on their details; but there will be later reference to some Sherman Act applications where these factors of immunity did not operate. For worthwhile discussions of the Apex and Hutcheson cases, see Pierce, Labor and the Antitrust Lawes, 8 So. CaL. L. REv. 17 (1945); MASON, HarLan FIsKe STONe 494-503 (1956). And see also Taylor, LABOR AND THE SUPREME COURT (1957), and Allen Bradley Co. v. Local Union No. 3. International Brotherhood of Electrical Workers, 325 U.S. 797 (1945) for the Court's version of the meaning of the Apex and Hutcheson cases in the context of the Sherman Act.

${ }^{10}{ }_{38}$ Stat. 730 (19 44$)$ ), 15 U.S.C. $\S \S \times 2$ et. seq. (1952); 47 Stat. 70 (1932), 18 U.S.C. $\$ 3692$ (1952).

${ }^{27}$ "We do not pause to comment on cases such as United States $v$. Knight, . . in which the undisputed facts showed that the purpose of the agreement was not to obstruct or restrain interstate commerce. The object and intention of the combination determined its legality." 208 U.S. at 297. For a lucid discussion of boycotts within the reach of the Sherman Act, see Kirkpatrick, Commercial Boycotts as Per Se Violations of the Sherman Act, to GEO. Wash. L. REV. 302, 387 (1942). For a recent boycott involving local conduct and held a violation of the Sherman Act see Evening News Publishing Co. v. Allied Newspaper Carriers of New Jersey, 160 F. Supp. 568 (D.N.J. 1958).

${ }^{18}{ }_{22}$ I U.S. I (191x). The Court referred to the Kuight case as involving mere questions of production which is beyond the reach of Congress, and said that the position and argument based on this idea "have been so necessarily and expressly decided to be unsound as to cause the contention to be plainly foreclosed and to require no express notice." Id. at 68. It is interesting to note that Chief Justice White, who wrote the opinion in the Standard Oil case, was one of the concurring justices in the Knight opinion.

${ }_{10}$ Dahnke-Walker Co. v Bondurant, 257 U.S. 282, 291 (1921), where the Court said that "contracts to buy, sell or exchange goods to be transported among several states are part of interstate commerce." United Leather Workers v. Herkert, 265 U.S. 457 (1924), suggesting that the Sherman Act would apply to a union strike designed to attempt to interfere with the free interstate movement of goods; United States v. Chicago, M. St.P. \& P.R.R. Co., 282 U.S. 311,326 (1931), where the Court observed that production may involve interstate commerce. In Mandeville Farms v. Sugar Co., 
At this juncture, however, there occurred a throwback-what is perhaps the nadir of all antitrust decisions. In Federal Baseball Chub v. National League, ${ }^{20}$ the Supreme Court, in a unanimous opinion written by Justice Holmes, held that organized, "big league" baseball was a noninterstate, noncommercial local venture in the exhibition of personal effort. ${ }^{21}$ This holding was issued in the face of the plaintiff's graphic contention that the business of the National and American Leagues was, in fact, an entirety and, as such, was interstate commerce. The plaintiff stressed the substantial and essential communication and travel across state lines and made clear the distinction between baseball as a sport and baseball as a business-the one being merely a means of physical exercise and diversion; the other an enterprise with a colossal investment, engaged for profit in providing exhibitions of athletic skill. Professional baseball, it was urged, in short, had all the features of any large, interstate, commercial undertaking. This argument, however, was of no avail. The Court did admit that "the scheme requires constantly repeated travelling on the part of the clubs, ..." and that "in order to give the exhibitions the Leagues must induce free persons to cross state lines and must arrange and pay for their doing so.... 322 But this transportation of persons, said the Court, was "a mere incident, not the essential thing.".23

This performance can be regarded as little short of a startling judicial aberration. In Hoke v. United States, ${ }^{24}$ some seven years earlier, the same Court, of which Mr. Justice Holmes was then too a member, unanimously had held that a single, isolated transportation of a woman across a state line for immoral purposes was interstate commerce. The Court reasoned that commerce among the states ${ }^{25}$

consists of intercourse and traffic between their citizens, and includes the transportation of persons and property. There may be, therefore, a movement of persons, as.well as of property; that is, a person may move or be moved in interstate commerce.

334 U.S. 219,229 (1948), the Court, in referring to the Knight case said: "It is true that the first decision under the Sherman Act applied those mechanical distinctions with substantially nullifying effects for coverage both of the power and of the Act."

${ }^{20} 259$ U.S. 200 (1922). This was a treble damage suit charging a violation of the Sherman Act. Since the jury returned a verdict for $\$ 80,000$ and the trial court entered judgment for three times this amount and attorneys fees, we must presume that both the jury and the judge found that, in fact, interstate commerce was involved.
${ }^{21}$ Id. at 208, 209.
${ }^{28} I d$. at 208.
29 Id. at 209 .
${ }_{22} 22$ U.S. 308 (1913).
${ }^{25} I d$. at 320 . 
In addition to Mr. Justice Holmes, three other justices were also members of the Court when it decided both the Hoke and the Federal Baseball cases. ${ }^{26}$

It is logically impossible to reconcile the Hoke and Federal Baseball decisions, ${ }^{27}$ and the latter subsequently did, in fact, rise to plague the Supreme Court in a series of lawsuits involving professional baseball, boxing, football, and theatre entertainment. To the Court's credit, however, it may be noted that the Federal Baseball doctrine bore unwelcome fruit only once, and then was rejected. In Toolson v. New York Yankees, Inc., ${ }^{28}$ the Court refused to overrule its earlier holding, for which it discerned possible tacit congressional approval. When subsequently asked in United States v. Shubert ${ }^{29}$ to vacate the ruling of a lower court that the Federal Baseball doctrine applied to the theatre business, however, the Court reversed the trial judge and affirmed its United States v. South-Eastern Underworiters Ass' $n^{30}$ holding that the requirement of "interstate commerce among the states" is satisfied by a continuous and indivisible stream of intercourse involving the sending across state lines of money and communications. Thus, the Federal Baseball and Toolson cases to the contrary notwithstanding, a restraint or monopolization of the theatrical business was held clearly to be within the scope of the Sherman Act, even though the actual performance of a stage attraction "is of course a local affair" and once interstate commerce is shown, the Sherman Act was held to be applicable even to "local" restraints on that commerce. ${ }^{31}$

To the same effect was the Supreme Court's holding in United States v. International Boxing Club of New York. ${ }^{32}$ There, the promotion of professional championship boxing contests on a multistate basis, coupled with the sales of rights to televise, broadcast, and film the contests for interstate transmission, was held to be within the scope of the Sherman Act if the conduct either imposes an illegal restraint on or con-

\footnotetext{
${ }^{20}$ The four Justices were Day, Holmes, McKenna, and Van Devanter.

${ }^{27}$ One possible explanation for the performance of Mr. Justice Holmes in the Federal Baseball case is apparent lack of sympathy with and understanding of the purpose of the antitrust laws. See LerNer, THE Mind and Faith of Justice Holmes xxxvi (1943), where Mr. Justice Holmes' dissent in the Northern Securibies Co. case is described and where he is said to have "approached the case without a feeling for the realities of economic power involved ...." See in this same connection id. at 217-22, for further light on the Justice's basic attitude toward the Sherman Act.

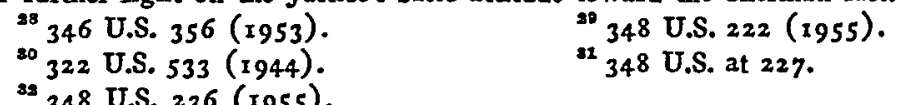

20 348 U.S. 222 (1955).

348 U.S. at 227 .

348 U.S. 236 (1955).
} 
stitutes interstate commerce. The Court realized that a boxing match is clearly a local matter, but regarded this fact as immaterial. ${ }^{33}$ And in Radovich v. National Football League, the Court likewise held that a conspiracy to monopolize organized professional football is within the reach of the antitrust laws. ${ }^{34}$

The recent baseball, theatre, boxing, and football cases evoked several concurring and dissenting opinions and a veritable flood of law review commentary. ${ }^{35}$ It is likely, however, that these four adjudications have firmly laid to rest the ghost of the Federal Baseball case, unless a baseball situation possibly forces a technical and reluctant adherence to precedent.

Following the ill-fated Federal Baseball decision, the Supreme Court continued to give some lip service to the so-called legal difference between conduct in the stream of interstate commerce and local intrastate conduct ${ }^{36}$-that is, until the Mandeville case. ${ }^{37}$ Decided entirely on the sufficiency of the plaintiff's amended complaint, this case apparently turned not only on specific allegations, but on economic facts regarding the effect upon interstate commerce of a price-fixing agreement on a purely local level of which the Court appeared to take judicial notice. The Court rejected the contention that the growing and selling of beets should be considered separate and distinct from the refining and marketing of their sugar. Since these various processes mvolved and coinprised an economic continuum, it was deemed necessary to consider not only the varying methods by which the several processes were organized, related, and conducted, but also the effects of production and processing on commerce across state lines.

Thus, it was considered irrelevant and unnecessary to search for a sharp point or a line where intrastate commerce ends and interstate commerce begins, the crucial inquiry rather being whether effects forbidden by the antitrust laws reach from processes occurring within to those occurring without the state. If a proscribed effect upon interstate com-

${ }^{23}$ Id. at 24.1 ,

84 352 .U.S. 445 (1957). Since this case turned on the sufficiency of the complaint, the Court assumed as true the allegations that the National Football League, its ten member clubs, and others had conspired to destroy a competitive league by boycotting it and its players and to do certain other described illegal acts.

${ }^{25}$ See Index to Legal Periodicals under the appropriate topics and names of cases for the period 1950 to date.

${ }^{20}$ E.g. United States v. Yellow Cab Co., 332 U.S. $2 \times 8$ (1947). (1952).

${ }^{27}$ See also in this connection, United States v. New Wrinkle, Inc., 342 U.S. 371 
merce is present, either actually or potentially, the vital question should only be whether this effect is sufficiently substantial to violate the Sherman Act. The Act, the Court indicated, would be inoperative only where the local conduct was not intended to have and did not have direct contact with interstate commerce. Price-fixing by purchasers wholly within a state, however, might be an inseparable element of a larger program dependent for its success upon activity which affects commerce between the states. The vital question, the Court held, was the effect of the local conduct on any phase of the commerce involved.

The Supreme Court made certain further observations. The mere change in the form of the commodity or even a complete change in essential quality by intermediate processing does not defeat the application of the Sherman Act to practices occurring either during those processes or before they begin when these practices have effects forbidden by law. In fact, the price-fixing agreement in question had a substantial effect on the sale of sugar outside of the state. Because the sale of sugar beets by the growers was completely dominated by the sugar refiners, who were the sole purchasers, two distinct consequences followed from the latter's agreement to pay uniform prices. An immediate and inevitable one was upon the price received by the growers, since they were deprived of the opportunity and freedom to dispose of their crops on a competitive basis. In addition, there was a necessary suppression of competition in the interstate distribution of sugar. Under the circumstances, therefore, the Court held as a matter of law that when a purely intrastate refining manufacturing process occurs as an intermediate step in an integrated industry which has interstate phases, the fact that such processing occurs on a local level is no defense in an antitrust case.

Another recent case which directly raised the same problem was Las Vegas Merchant Plumbers Assn v. United States. ${ }^{38}$ There, the court expressly distinguished between conduct in the stream of interstate commerce and intrastate conduct which substantially affects interstate commerce. ${ }^{30}$ The court's lengthy analysis took the following tack: Conduct may "affect" interstate commerce in two different ways in an antitrust context, both of which may warrant prosecution. First, conduct may occur wholly on the local or state level in intrastate com-

\footnotetext{
${ }^{38} 210$ F.2d 732 (9th Cir. 1954), cert. denied, 348 U.S. 817 (1954).

${ }^{30}$ In support of this difference, the Court cited the Mandeville case and United States v. Chrysler Corporation, 180 F.2d 557, 560 (9th Cir. 1950).
} 
merce, but substantially affect interstate commerce. These intrastate acts may occur before goods enter the flow of commerce, and their ultimate effect or impact on interstate commerce need only be a qualitative, and not a quantitative, one. This is either a question of law or a mixed question of law and fact. ${ }^{40}$ A price-fixing agreement on a purely local basis is not a per se violation of the Sherman Act and is outside the operation of this statute, however, unless it, in fact, "substantially affects" interstate commerce.

In addition and in contrast to the intrastate situation is the "in commerce" situation, involving acts occurring within the flow of interstate commerce. These acts, like those occurring in intrastate commerce, must affect or have an effect on interstate commerce, and their ultimate effect or impact on interstate commerce, too, need only be a qualitative one. As a matter of law, an agreement to fix prices or to divide markets is a violation per se. Otherwise, the effect of an alleged illegal transaction may be a question of law or a mixed question of law and fact. Thus, agreements to fix prices ${ }^{41}$ or agreements to divide markets ${ }^{42}$ are unreasonable per se, and the final effect of either of such agreements on interstate commerce and the substantiality of their effect become questions of law under the facts.

The court did not clearly delineate its decisional process in formulating the legal doctrines governing the particular type of transaction involved here nor in specifying the circumstances which would bring them into operation. There is some doubt as to just what the court meant. when it said that the test of the ultimate effect or impact of wholly intrastate acts on interstate commerce is a question of law or a mixed question of law and fact. If it is a question of law, the court did not - verbalize, either generally or particularly, the circumstances of the transaction, except in terms of "ultimate effect or impact of the act on interstate commerce." The tenor of the opinion, however, seems to indicate that mere price-fixing in a local transaction, without more, is immune from the Sherman Act. The court also appeared disinclined to assume factual effects or to take judicial notice of them, as other courts appear to have done. Nevertheless, support is found in other judicial opinions for the view that under the "affectation doctrine," the boundary

${ }^{\circ}$ In support of this view the court cited the Mandeville case, the Addyston case, and United States v. General Motors Corp., 12 I F.2d 376 (7th Cir. 1941), cert. denied, 314 U.S. 618 (1941).

"Citing United States v. Socony-Vacuum Oil Co., 3 10 U.S. 150, 223 (1940).

${ }^{42}$ Citing the $A d d y s t o n$ case. 
line between intrastate and interstate commerce is no longer to be regarded a material matter. The Supreme Court, both years ago and recently, recognized the difficulty of defining the precise line, ${ }^{43}$ but since it is functionally artificial ${ }^{44}$ and indecisive, ${ }^{45}$ its exact location is of slight import if an adverse effect on interstate commerce follows. ${ }^{48}$

Under the "affectation doctrine," the effect upon interstate commerce which must be shown is said to be substantial. Further, the courts have held that it need be only qualitative, ${ }^{47}$ and not quantitative..$^{48}$ Hence, the Sherman Act has been construed to forbid wholly intrastate conduct if interstate commerce feels its pinch. ${ }^{40}$ The local conduct need only be intimately related to and have an essential adverse effect on

${ }^{43}$ See note 14 stipra. In United States v. Employing Plasterers Ass'n, 347 U.S. 186, 189 (1954), the Court said: "Where interstate commerce ends and local commerce begins is not always easy to decide and is not decisive in Sherman Act cases." See the dissents by Justices Minton and Douglas. They agreed with their brethren as to the substantive content of the affectation doctrine but disagreed with the particular inferences of fact of the majority as to adverse impact on the journey across state lines in that case. In Local I67, International Brotherhood of Teamsters v. United States, 291 U.S. 293, 297 (1934), the Court said: "It may be assumed that some time after delivery of carload lots by interstate carriers to the receivers the movement of the poultry ceases to be interstate commerce. ... But we need not decide when interstate commerce ends and that which is intrastate begins."

"Sandeville Farms v. Sugar Co., 334 U.S. 219, 230 (1948).

¿s United States v. Employing Plasterers Ass'n, 347. U.S. 186, 189 (1954).

${ }^{48}$ Mandeville Farms v. Sugar Co., 334 U.S. 219, 232 (1948); United States v. Women's Sportswear Manufacturers Ass'n, 336 U.S. 460, 464 (1949). See also Stevens Company v. Foster \& Kleiser Co., 31 I U.S. 255, 261 (1940).

${ }^{47}$ The effect on interstate commerce is enough if it is injurious, stifling, obstructive, burdensome or adverse. See note 48 infra. See also United States v. Wrightwood Dairy Co., 315 U.S. 110, 120 (1942). The character of the restraint is immaterial. Montague \& Co. v. Lowry, 193 U.S. $3^{8}$ (I904).

"The amount of the adverse effect is immaterial. Montague \& Co. v. Lowry, 193 U.S. 38 (1904); Apex Hosiery Co. v. Leader, 310 U.S. 469 (1940); United States v. McKesson \& Robbins, Inc, 351 U.S. 305,310 (2956). "There is no act of interstate trade or commerce so insignificant as not to be protected. ... Clearly, then, a conspiracy ... in restraint of a single interstate sale or shipment of another competitor is covered. ..." Patterson v. United States, 222 Fed. 599, 619 (6th Cir. 1915). See also United States v. Columbia Steel Co., 334 U.S. 495, 522 (1948). "Further we need not be concerned with the amount of interstate commerce affected because 'large or small' it is covered by the Act." United States v. Milk Drivers Union, I53 F. Supp. 803, 807 (D. Minn. 1957). See, however, United States v. Oregon State Medical Soc'y, 343 U.S. 326,338 (1952), where the Court suggested that a group medical service does not lose its character of a wholly intrastate business merely because it made a few sporadic and incidental out-of-state payments to doctors and hospitals.

${ }^{49}$ United States v. Women's Sportswear Manufacturers Ass'n, 336 U.S. 460,464 (x 948); United States v. Employing Plasterers' Ass'n, 347 U.S. 186 (1954); United States v. New Orleans Insurance Exchange, 148 F. Supp. 915 , aff'd, 355 U.S. 22 (1957). 
the flow across a state line of a subject matter of trade. ${ }^{50}$ To violate the antitrust laws, this conduct must, however, have a result which is more than merely casual, incidental, remote, conjectural, sporadic, or unsubstantial. ${ }^{.1}$

The criterion of "close and substantial" relation between intrastate activities and interstate commerce is a practical standard, and not a technical concept. ${ }^{52}$ Essentially it poses a question of degree, and hence it is not susceptible of rigid formulation. ${ }^{53}$ Thus, an artificial or mechanical rule will not work; ${ }^{54}$ close scrutiny of the particular facts of each situation rather is needed in the context of our expanding national economy. 55

There is considerable indication in the recent opinions as to what meets the test of "substantial qualitative effect" on interstate commerce.

${ }^{80}$ Santa Cruz Co. v. Labor Board, 303 U.S. 453, 466 (1938); United States v. Women's Sportswear Manufacturers Ass'n, 336 U.S. 460, 464 (1948); United States v. General Motors Corp., 121 F.2d 376, 402 (7th Cir.), cert. denied, $3^{\text {r.4 U.S. } 618}$ (1941). See also United States v. Yellow Cab Co., 332 U.S. 218,230 (1947).

${ }_{\text {B1 }}$ United States v. Yellow Cab Co., 332 U.S. 218,231 (1947); United States v. San Francisco Electrical Contractors Ass'n, 57 F. Supp. 57 (N.D. Cal. r944); United States v. Employing Lathers Ass'n, 118 F. Supp. 387 (N.D. Ill. 1953), rev'd on other grounds, 347 U.S. 198 (1954). See also United States v. Starlite Drive-In, Inc., 204 F.2d 419 (7th Cir. 1953 ).

s5 "Commerce among the states is not a technical legal concept, but a practical one, drawn from the course of business." Swift and Co. v. United States, 196 U.S. 375, 398 (1905). In Stafford v. Wallace, 258 U.S. 495, 519 (1922), the Court said it would decline to defeat the purpose of the interstate commerce clause "by a nice and technical inguiry into the non-interstate character of some of its necessary incidents and facilities when considered alone. ..."

"Santa Cruz Co. v. Labor Board, 303 U.S. 453, 466-68 (1938). "Not every act that may be done with intent to produce an unlawful result is unlawful; or constitutes an attempt. It is a guestion of proximity or degree." Swift and Co. v. United States, 196 U.S. 375,402 (1905).

"Santa Cruz Co. v. Iabor Board, 303 U.S. 453, 468 (1938). "The restrictions imposed by the Sherman Act are not mechanical or artificial ... they set up the essential standard of reasonableness." Sugar Institute v. United States, 297 U.S. 553,597 (1936). In rejecting the alleged distinction between a union's intention to close a plant but not to obstruct interstate commerce, the Court said in Apex Hosiery Co. v. Leader, 3 ro U.S. 469,509 (1940): "But we are not relegated to so mechanical an application of these cryptic phrases in the application of the Sherman Anti-Trust Act. . . " See also, Appalachian Coals, Inc. v. United States, 288 U.S. 344, 360 (1933).

${ }^{B s}$ Santa Cruz Co. v. Labor Board, 303 U.S. 453, 467-68 (1938); Stafford v. Wallace, 258 U.S. 495, 518 (r 922 ). In Appalachian Coals, Inc. v. United States, 288 U.S. 344, 360-61 (1933), the Court said: "In applying this test, a close and objective scrutiny of particular conditions aud purposes is necessary in each case. Realities must dominate the judgment. . . The question of the application of the statute is one of intent and effect, and is not to be determined by arbitrary assumptions." 
The legal standard employed comprises ingredients which range from the relatively specific to the general. The following have been adduced as proof of the "substantial qualitative effect" essential to an offense:

(a) an increase of price to consumer $;^{56}$

(b) a reduction of amount of consumption; ${ }^{5 T}$

(c) an impairment of quality; ${ }^{58}$

(d) a decrease in interstate movement; ${ }^{59}$

(e) a change of direction of interstate movement; ${ }^{80}$

(f) a retardation of flow of interstate movement; ${ }^{61}$

(g) a narrowing of markets; ${ }^{62}$

(h) a burdening of interstate movement; ${ }^{63}$.

(i) an impairment of benefits of free competition; ${ }^{64}$ and

(j) an elimination of price competition. ${ }^{65}$

Within the last twenty years, the Sherman Act has operated on a variety of local acts which were held to have had an adverse impact upon the stream of interstate commerce. Among those worthy of noting here are:

${ }^{80}$ United States v. Chrysler Corporation, 180 F.2d 557 (9th Cir. 1950); United States v. San Francisco Electrical Contractors Ass'n, 57 F. Supp. 57 (N.D. Cal. 1944); United States v. Universal Milk Bottle Service, 85 F. Supp. 622 (S.D. Ohio 1949); United States v. Detroit Sheet Metal and Roofing Contractors Ass'n, 116 F. Supp. 81 (E.D. Mich. 1953).

${ }^{57}$ United States v. San Francisco Electrical Contractors Ass'n, 57 F. Supp. 57 (N.D. Cal. r944) (dictum); United States v. Universal Milk Bottle Service, 85 F. Supp. 622 (S.D. Ohio 1949); United States v. Detroit Sheet Metal \& Roofing Contractors Ass'n, 116 F. Supp. 8I (E.D. Mich. 1953).

${ }^{88}$ United States v. Universal Milk Bottle Service, 85 F. Supp. 622 (S.D. Ohio 1949).

${ }_{59}$ United States v. Starlite Drive-In, Inc., 204 F.2d 419 (7th Cir. 1953); United States v. Greater Kansas City Chapter Nat'l Electrical Contractors Ass'n, 82 F. Supp. 147 (W.D. Mo. 1949).

${ }^{\circ 0}$ United States v. Starlite Drive-In, Inc., 204 F.2d 419 (7th Cir. 1953).

ox United States v. Detroit Sheet Metal \& Roofing Contractors Ass'n, 116 F. Supp. 81 (E.D. Mich. 1953); United States v. Food and Grocery Bureau, 41 F. Supp. 884 (S.D. Cal. 1941), aff'd, 139 F.2d 973 (9th Cir. 1943).

${ }^{62}$ Las Vegas Merchant Plumbers Ass'n v. United States, 210 F.2d 732, (gth Cir. 1954), cert. denied, 348 U.S. 817 (1954).

${ }_{63}$ United States v. Chrysler Corporation, 180 F.2d 557 (9th Cir. 1950).

os United States v. Detroit Sheet Metal \& Roofing Contractors Ass'n, II 6 F. Supp. 81 (E.D. Mich, 1953).

${ }^{\circ}$ United States v. Chrysler Corporation, 280 F.2d 557 (gth Cir. 1950); Las Vegas Merchant Plumbers Ass'n v. United States, 210 F.2d 732 (gth Cir. 1954), cert. denied, 348 U.S. 817 (1954); United States v. Detroit Sheet Metal \& Roofing Contractors Ass'n, 116 F. Supp. 8x (E.D. Mich, 1953). 
(a) an agreement between electrical contractors, manufacturers and a union, all in the same locality, providing that the contractors should buy only from the manufacturers who should sell only to contractors employing members of the union; ${ }^{68}$

(b) an agreement between a group of local manufacturers of lumber products and a group of trade unions and their officials and business agents providing that the former should refuse to purchase any materials or articles on which any work was done by a mill, a cabinet shop, or distributor for wages or under working conditions failing to conform to those specified in the agreement; ${ }^{67}$

(c) an agreement between garment jobbers and an asociation of stitching contractors and its officers providing (I) that the jobbers should give all their work to members of the association in good standing if their price and quality compared with those of nonmember contractors who had collective-bargaining agreements with a certain union, (2) that the contractors should refrain from giving the jobbers any secret rebates, and (3) that the jobbers should divide the work equally among the members of the association; ${ }^{68}$

(d) an agreement between a trade association of local plastering contractors and a local union providing that they should suppress competition among the plasterers, prevent out-of-state contractors from doing business in the local area, and bar the entry of new local contractors without the approval of a private examining board created by the union; ${ }^{69}$

(e) an agreement between milk dairies and a milk-drivers' union providing that the parties should prevent retail stores from selling milk for a price less than that charged by the dairies for home deliveries; ${ }^{70}$

(f) an agreement among an insurance exchange and its member agencies providing that they should maintain a boycott against all normember insurance agencies and all insurance companies which did not plant exclusively through the exchange outlets or its members; ${ }^{71}$

(g) an agreement among the members of a home-delivery news-

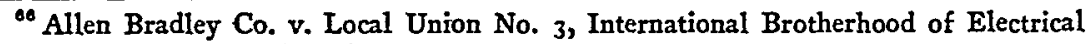
Workers, 325 U.S. 797 (1945).

${ }^{67}$ United Brotherhood of Carpenters v. United States, 330 U.S. 395 (1947).

${ }^{\text {os }}$ United States v. Women's Sportswear Manufacturers Ass'n, 336 U.S. 460 (r949).

${ }^{10}$ United States v. Employing Plasterers Ass'n, 347 U.S. 186 (1954).

${ }^{70}$ United States v. Milk Drivers \& Dairy Workers Union, 153 F. Supp. 803 (D. Minn. 1957).

${ }^{22}$ United States v. New Orleans Insurance Exchange, 148 F. Supp. 915 (E.D. La. 1957), aff'd, 355 U.S. 22 (1957). 
dealers' association that they should boycott a newspaper unless it required newsboys making street sales of its papers to withdraw from areas in which the members of the association operated ${ }^{72}$

(h) an agreement among plumbing contractors that they should fix prices and divide markets by (I) using an estimator who should determine the price to be charged for a job, an allocation committee who should decide which contractor should bid, and an agent who should induce journeymen and apprentice plumbers to work only for a contractor designated for the job, and (2) boycotting wholesalers who offered to sell supplies at terms and prices not agreeable to the contractors; ${ }^{73}$

(i) an agreement between an association of local lathing contractors and a local union providing that they should (I) limit the number of contractors, (2) prescribe their qualifications, (3) decide what contractors met these qualifications, (4) exclude persons from the contracting business on various grounds including arbitrary racial standards, and (5) assign plastering contractors to lathing contractors; ${ }^{74}$

(j) an agreement among a retail grocers association and its members providing that the latter should refrain from selling below price lists; ${ }^{75}$

(k) an agreement among members of a retail grocers association providing that they should stabilize prices by refraining from selling below those prices fixed by the association by maintaining a six per cent mark-up and by refraining from advertising and selling for less than this mark-up; ${ }^{76}$ and

(1) an agreement between an automobile manufacturer and dealers providing that they should tie the sales of automobiles to the financing of such transactions. ${ }^{77}$

The first six situations described were cases where the defendants tried in vain to invoke the claim of statutory exemption from the Sherman Act based, respectively, on the Clayton and Norris-LaGuardia Acts,

\footnotetext{
"Evening News Publishing Co. v. Allied Newspaper Carriers, 160 F. Supp. 568 (D.N.J. 1958).

${ }^{3}$ Las Vegas Merchant Plumbers Ass'n v. United States, 210 F.2d 732 (9th Cir. 1954), cert. denied, 348 U.S. 817 (1954).

${ }^{34}$ United States v. Employing Lathers Ass'n, 347 U.S. 198 (1954).

${ }^{78}$ United States v. Food and Grocery Bureau, 41 F. Supp. 884 (S.D. Cal. 1941), aff'd, 139 F.2d 973 (9th Cir. 1943).

${ }^{76}$ California Retail Grocers \& Mercliants Ass'n v. United States, 139 F.2d 978 (9th Cir. 1943), cert. denied, 322 U.S. 729 (1944).

${ }^{77}$ United States v. General Motors Corp., 121 F.2d 376 (7th Cir. 1941), cert. denied, 314 U.S. 618 1941).
} 
involving labor unions, and the $\mathrm{McCarran} A c t,{ }^{78}$ relating to the insurance business. $^{79}$ The Supreme Court held that Congress never intended that organized labor should be free to combine with businessmen to suppress competition, create a monopoly, or control the marketing of goods and services, even if such action were prompted by a desire to further the interests of the wage-earner members of a union. ${ }^{80}$ The "benefits to organized labor cannot be utilized as a cats-paw to pull employers' chestnuts out of the antitrust fires." ${ }^{381}$ And Congress clearly did not intend that agreements to boycott, coerce, or intimidate in the insurance field should be immune from the antitrust laws. ${ }^{82}$

The defense of "local conduct outside the Sherman Act" has succeeded in several lawsuits within recent years. The most notable is the first Yellow Cab case. ${ }^{83}$ Because the Supreme Court failed completely to analyze all of the issues, its decision, in part, is of uncertain meaning and questionable soundness. The defendants were a passenger transportation company moving only between railroad terminals in Chicago, Illinois, and two firms which did not engage in this business but otherwise operated a general taxicab service throughout the city. The complaint charged a conspiracy (a) to restrain and monopolize interstate commerce in the sale of taxicabs in Chicago and three other large cities, (b) to refrain from competing in the business of transporting interstate passengers between railroad stations in Chicago, and (c) to induce the City of Chicago to limit the number of licensed taxicabs and to issue eighty-six per cent of the licenses to the two defendants operating the city-wide taxicab service. The trial court regarded the business here as "an independent local service" beyond the scope of the Sherman Act ${ }^{34}$ and, accordingly, dismissed the suit.

The Supreme Court reversed the lower court, but only as to the first

${ }^{58} 59$ STAT. 33,34 (1945), 15 U.S.C. $\$ \$$ Iori-1015 (1952).

${ }^{70}$ See addresses on these subjects by Victor R. Hansen, Assistant Attorney General in Charge of the Antitrust Division of the United States Department of Justice: Important Questions of the Day (Antitrust), before the National Association of Mutual Insurance Agents, Oct. x 5, 1957, Chicago, Ill., Current Progress and Problems of Antitrust, before the New York Bar Association, Jan. 30, 1958, New York, N. Y.

"See notes 66-70 supra.

${ }^{31}$ United States v. Women's Sportswear Manufacturers Ass'n, 336 U.S. 460,464 (1949).

United States v. New Orleans Insurance Exchange, 148 F. Supp. 915 (E.D. La. 1957), aff'd, 355 U.S. 22 (1957).

ss United States v. Yellow Cab Co., 332 U.S. 2 I 8 (1947).

"United States v. Yellow Cab Co., 69 F. Supp. 170, 173 (N.D. Ill. 1946). 
two charges. In holding the complaint sufficient as to the second charge, the Court said that the conveying of travelers between railroad terminals of the city was "clearly a part of the stream of interstate commerce." In support of this ruling, the Court relied on The Daniel Ball.86 This leading case involved a boat which operated entirely within Michigan in transporting goods which moved across the state lines. The Court had held that the vessel was engaged in interstate commerce: ${ }^{87}$

So far as she was employed in transporting goods destined for other States, or goods brought from without the limits of Michigan and destined to places within that State ... she was employed as an instrument of that commerce. . . . The fact that several different and independent agencies are employed in transporting the commodity, some acting entirely within one State, and some acting through two or more States, does in no respect affect the character of the transportation.

The Government expressly cited The Daniel Ball in its brief in the Yellow $C a b$ case in support of its contention that the service rendered by local taxicabs in conveying interstate passengers between their homes, offices, or hotels and railroad stations was within the reach of the Sherman Act and that the alleged conspiracy of the defendants to persuade the City of Chicago to limit the number of taxicabs was, therefore, a violation of the Act. In rejecting this contention, the Supreme Court held that "such transportation is too unrelated to interstate commerce to constitute a part thereof within the meaning of the Sherman Act," because the relationship of the taxicabs "to interstate transit is only casual and incidental." The Court did suggest, however, that although the normal operation of a general local taxicab service is not an integral part of interstate transportation, a conspiracy to burden or eliminate transportation of passengers between their homes and a railroad station might have sufficient effect' upon interstate commerce to justify using the Sherman Act. ${ }^{80}$

The opinion unfortunately casts but little light on the problem. The Supreme Court did not furnish any guide as to the kind, amount, and circumstances of adverse impact on interstate movement which it said

\footnotetext{
${ }^{85}$ United States v. Yellow Cab Co., 332 U.S. 218,228 (1947).

${ }^{88} 77$ U.S. (10 Wall.) 557 ( 1870 ).

${ }^{87}$ Id. at 565 .

${ }^{8 s}$ United States v. Yellow Cab Co., 332 U.S. $218,230,231$ (1947).

${ }^{82}$ Id. at 233 .
} 
might invoke the antitrust laws. Some of its language and citations would seem to apply equally well to the transportation of a passenger from his home to a terminal as from one station to another. ${ }^{90}$ Furthermore, the doctrine of The Daniel Ball would appear to be applicable and, in fact, has been followed in situations functionally analogous. Thus, a local telephone company was held to be an instrument of interstate commerce in the transmission of interstate messages to and from the points it served, although its business was mainly the transmission of intrastate messages over lines lying entirely within one state. ${ }^{21}$ To the same effect is a ruling with reference to a common carrier which operated wholly within a state and transported goods in continuous passage from outside the state to its stations. ${ }^{92}$

It is, therefore, hard to reconcile the Yellow Cab case with the doctrine that Congress sought to go to the limit of its power in curbing restraints of trade ${ }^{93}$ and with the basic principle that the antitrust laws prohibit local conduct which adversely affects interstate commerce. ${ }^{91}$ The opinion in the Yellow Cab case also fails to answer other vital questions. For example, it does not say where interstate commerce begins and ends; whether this inquiry is one of fact or law; what, if any, presumptions are used; and how the facts are to be determined. It

${ }^{00}$ "When persons or goods move from a point of origin in one state to a point of destination in another, the fact that a part of that journey consists of transportation by an independent agency solely within the boundaries of one state does not make that portion of the trip any less interstate in character. . . . That portion must be viewed in its relation to the entire jonrney rather than in isolation. So viewed, it is an integral step in the interstate movement. See Stafford v. Wallace, 258 U.S. 495." Id. at 228-29. In the Stafford case, the Court held that the business of commission 'merchants in the stockyards of Chicago was as essential part of the interstate movement of livestock to that city.

${ }^{01}$ NLRB v. Central Missouri Telephone Co., ix 5 F.2d 563 (8th Cir. 1940).

${ }^{92}$ United States v. Colorado \& N.W.R.R. Co., 157 Fed. 321 (8th Cir. 1907), cert. denied, 209 U.S. 544 (1908); accord, Kach v. Monessen Southwestern Ry. Co., 15 I F.2d 400 (3d Cir. 1945); Walling v. Rockton \& Rion R.R., 54 F. Supp. 342 (W.D.S.C. I944), aff'd, 146 F.2d 11 1 (4th Cir. 1944), cert. deried, 324 U.S. 880 (1945).

${ }_{08}$ United States v. South-Eastern Underwriters Ass'n, 322 U.S. 533,558 (1944). Cf. Hoke v. United States, 227 U.S. $308,320(1913)$; United States v. Capital Transit Co., 325 U.S. 357 (1945); Sprout v. City of South Bend, 277 U.S. 163, 168 (x928); United States v. Frankfort Distilleries, Inc., 324 U.S. 293; 298 (1945); Apex Hosiery Co. v. Leader, 310 U.S. 469,495 (r940).

is In addition to the various cases heretofore cited, see also Currin v. Wallace, 306 U.S. x (1939); Honston, E. \& W. Texas Ry. v. United States, 234 U.S. 342 (x914). See also the interesting comment on the Yellow Cab case in 32 IowA L. REV. 797 ( 1947 ). See also Tarnay, Methods For Differentiating Interstate Transportation From Intrastate Transportation, 6 GEO. WASH. L. REv. 553, 562, 630 (1938). 
further appears that the Supreme Court, by way of judicial notice, made a sweeping a priori finding of fact as to what was the normal course of operation of local taxicab companies, and then formulated, in general terms, a legal principle of considerable proportions, but without objective content. ${ }^{95}$ The sound and practical course for the Court might rather have been, however, to have avoided any decision based only on the pleadings as to whether taxicab transportation in the particular setting was intrastate rather than interstate commerce. The Court more wisely might have remanded the case to the trial court for a determination whether the alleged conspiracy in question had any adverse impact on the movement across state lines of any persons or property in the light of all the relevant realities of the local situation.

Under the "affectation doctrine," there are several holdings to the effect that certain price-fixing agreements at a purely local level do not violate the Sherman Act. In United States v. Starlite Drive-In, ${ }^{90}$ the court held that an agreement among theatre exhibitors to charge uniform admission prices does not have the requisite effect on interstate commerce to be illegal. The court indicated, however, that an increase, decrease, or change of direction of movement of films from one exhibitor to another would have the kind of impact on interstate commerce that is prohibited under the antitrust laws. In United States v. San Francisco Electrical Contractors Ass ${ }^{97}$ the court held that an adverse effect on the flow of goods caused by conduct in the course of collective bargaining by employers and employees is not the kind of interference with interstate commerce which the Sherman Act forbids. Therefore, the higher prices and smaller volume of goods which follow an agreement in such a situation are regarded as merely inconsequential, remote, and unsubstantial results of legitimate labor activities, and not products of an illegal combination to fix prices. And recently, in United States $v$.

${ }^{\circ 5}$ The Court based its decision mostly on the facts that the taxicabs (a) did not cross state lines, (b) by law operated only within the city, (c) had to serve every person, (d) had no arrangement with any interstate railroad, (e) were paid only by the passenger, (f) were commonly understood to be engaged only in intrastate traffic, (g) were but one means of conveyance, and (h) intermingled local passengers with interstate travelers. It is the view of the writer that these tests are not realistic or practical. Many seem to be irrelevant, and none goes to the very crux of the inquiry before the Court as to whether interstate commerce was restrained or monopolized.

${ }_{20} 204$ F.2d 419 (7th Cir. I 953).

${ }^{97} 57$ F. Supp. 57 (N.D. Cal. I 944). To the same effect is Atlantic Co. v. Citizens Ice \& Cold Storage Co., I 78 F.2d 453 (5th Cir. 1949), cert. denied, 339 U.S. 953 (1950); Spears Free Clinic and Hospital v. Cleere, 197 F.2d.125 (rotb Cir. 1952). 
Foremost Dairies, Inc., the court, after trial, based its dismissal of an indictment charging price-fixing on the ground that the Government had failed to establish the interstate nature of any other than a very minimal amount of any products supplied to the purchasers. ${ }^{98}$

In the course of applying the "affectation doctrine" to intrastate conduct, some courts appear to be making findings of fact independent of the pleadings or evidence before them. In the Mandeville Farms case, mentioned above, which was decided on the sufficiency of the plaintiff's amended complaint, the Court appears to have taken judicial notice of some effects of purely local conduct on interstate commerce when it said: 99

There were indeed two distinct effects flowing from the agreement for paying uniform prices, one immediately upon the price received by the grower rendering it devoid of all competitive influences in amount; the other, the necessary and inevitable effect of that agreement in the setting of the industry as a whole, to reduce competition in the distribution of sugar.

The Court there said, in substance, that it is impossible to accept the idea that stabilization of prices paid for the only raw material consumed in an industry has no tendency to reduce competition in the distribution of a finished product in an integrated industry, such as was involved in that case. The Court further observed that the foregoing effects, which permeated the entire structure of and were reflected throughout the industry, were the necessary and inevitable results of the agreement among the refiners to pay uniform prices for beets in the circumstances of the case. ${ }^{100}$

In United States v. Detroit Sheet Metal Roofing Ass' $n$, ${ }^{101}$ the court likewise appeared to take judicial notice of the effects on interstate commerce of a price-fixing scheme occurring after the interstate movement of the goods had come to an end. In this case, the indictment alleged that the necessary effect of the price-fixing agreement in question was (a) to suppress and eliminate competition, (b) to establish noncompetitive prices, (c) to establish high prices, and (d) to deny to consumers the benefits of free competition. In the course of holding this indictment sufficient, the court apparently took it for granted that if these

\footnotetext{
${ }^{98}$ No. 10,037 Cr. J.D.C. S.D. Fla. April 3, 1958, p. $238_{3}$ of trial transcript.

${ }^{20} 334$ U.S. at 241 .

${ }^{100}$ Id. at 242 .

${ }^{203} 116$ F. Supp. 81 (E.D. Mich. 1953).
} 
general seemingly local effects occurred, they would be followed by certain specific consequences to interstate commerce, observing::02

The fixing and maintenance of high prices for roofing construction and repair points to a reduction in the volume of such activity with a resultant reduction in the consumption of roofing materials, and a retardation of the flow of such materials from the out-of-state manufacturers throughout interstate channels of distribution. The effects of price-fixing have acquired such recognized status in the antitrust laws that when such a charge is made, I am compelled to take cognizance of such effect in reading the indictment.

In United States v. Universal Milk Bottle Service, ${ }^{103}$ the indictment charged that effects of a price-fixing agreement were (a) to increase the price of the commodity involved to consumers, (b) to reduce the amount to consumers, and (c) to impair its quality. The court said that the "fixing of prices as alleged in the indictment necessarily operates as a direct and substantial restraint in the interstate commerce herein involved."104 It seems, therefore, that the court, again, was making an a priori finding of fact-one not based on facts supplied by the pleadings or evidence-that such effects on interstate commerce are unavoidable.

United States v. Northeast Texas Chapter, ${ }^{105}$ appears to be another case where the court made an independent finding of fact of the effect on interstate commerce of a local price-fixing agreement. The indictment- here verbalized the effects of the price-fixing agreement on interstate commerce in terms only of "restraint." Yet, the court rejected the defendant's contention that such transactions do not directly affect or tend to affect a restraint upon interstate commerce, saying: ${ }^{106}$

In the very nature of trade and commerce alleged, these agreemients, some per se, and others as matter of fact, constitute an illegal restraint upon interstate commerce. ...

The foregoing analysis of intrastate commerce affecting interstate commerce indicates that the standard of "affectation" is still fluid. To date; this doctrine has been phrased in both general and particularized factual terms. There is some evidence in judicial opinions that the

\footnotetext{
${ }^{109} I d$. at 88.

${ }^{104} I d$. at 627 .

${ }^{103} 85$ F. Supp. 622 (S.D. Ohio 1949).

18 I F.2d 30 (5th Cir. 1950).

Id. at 33. Cf. United States v. Employing Plasterers Ass'n, 347 U.S. 186 (1954); United States v. Employing Lathers Ass'n, 347 U.S. 198 (1954).
} 
distinction made by the court in the Las Vegas Merchant Plumbers case between price-fixing as a per se violation under the "in commerce" theory and price-fixing as a per se violation under the "affect commerce" theory is becoming less sharp. The growing trend may be in the direction of attaching general legal significance to the specific circumstance of local price-fixing or boycotting or any other local conduct affecting persons, property, or communications moving across state lines. If this occurs, the courts may then consider such intrastate conduct as at least presumptive evidence of the more broadly stated, but perhaps no more precisely defined, vital fact of "adverse affect upon interstate commerce." The consequences of such subdefinition may be to increase the impact of the antitrust laws on purely local business activities. The likely result would be a general proposition applicable to an entire class of cases. The courts will probably then, as a matter of fact, judicially notice that where price-fixing, and perhaps other conduct, wholly within a state is an inseparable element of an integrated industry having interstate economic continuity, it necessarily affects interstate commerce. If so, the courts will, as a matter of law, hold that such price-rigging or other conduct with the same end result is a per se Sherman Act violation.

We can conclude our canvass of the applicability of the Sherman Act to local conduct with a few basic observations. What is involved is not the narrow type of legal precept which is clear and objective in content and automatic in operation. It is, rather, a practical standard requiring a rigorous analysis of the facts. The courts have generally been aware of the economic facts of life. Accordingly, they have realized that it would be utterly futile to try to find the precise line which separates interstate from intrastate commerce, that the focal point of the antitrust laws is rather the adverse impact on free movement of trade across state lines. Avoiding a jurisprudence of rigidity, the courts have generally used a functional approach. They have thus given life to a basically workable doctrine which makes for an effective enforcement of the antitrust laws. 